\title{
THE GREAT PATRIOTIC WAR IN RUSSIAN HISTORY TEXTBOOKS
}

\begin{abstract}
The topic of this article is presenting how the Great Patriotic War (GPW) is depicted in Russian national history textbooks. Here, I consider textbooks not only as a source of knowledge about the past times, but first and foremost as a tool to create the state's historical policy. I examine the GPW, in turn, as a fundamental myth of the Russian society which-without any doubt-constitutes one of the main pillars of identity of modern Russians. Another subject of this study is the changes in Russian education that took place in 2013-2015, that is during the presidency of Vladimir Putin. In so doing, I focus primarily on the creation of the Concept of a new educational and methodological complex for teaching national history and the introduction of new national history textbooks (the idea of the so-called "single textbook"). I strive to show in the article that the picture of the GPW in the new textbooks is mainly based on success_-of the Red Army, the Union of Soviet Socialist Republics and the Soviet nation.
\end{abstract}

Key words: the Great Patriotic War; history teaching; Russia; historical policy; Vladimir Putin

\section{WIELKA WOJNA OJCZYŹNIANA W ROSYJSKICH PODRECCZNIKACH DO HISTORII OJCZYSTEJ}

\section{Streszczenie}

Tematem niniejszego artykułu jest sposób przedstawiania Wielkiej Wojny Ojczyźnianej (WOW) w rosyjskich podręcznikach do historii ojczystej. Podręczniki traktuję przy tym nie tylko jako źródło wiedzy o czasach dawnych, lecz przede wszyst-
DAGMARA MOSKWA Instytut Studiów Politycznych Polskiej Akademii Nauk, Warszawa E-mail: moskwadagmara@gmail.com

CITATION: Moskwa, D. (2018). The Great Patriotic War in Russian History Textbooks. Sprawy Narodowościowe. Seria nowa, 2018(50). https://doi.org/10.11649/sn.1650

This work was supported by the author's own resources. No competing interests have been declared.

This is an Open Access article distributed under the terms of the Creative Commons Attribution 3.0 PL License (creativecommons.org/licenses/by/3.0/pl/), which permits redistribution, commercial and non-commercial, provided that the article is properly cited. (C) The Author(s) 2018.

Publisher: Institute of Slavic Studies, Polish Academy of Sciences 
kim jako narzędzie kreowania polityki historycznej państwa. WOW rozpatruję z kolei w kategoriach podstawowego mitu społeczeństwa rosyjskiego, który - ku czemu nie ma wątpliwości - stanowi jeden z podstawowych filarów tożsamości współczesnych Rosjan. Przedmiotem badań są także zmiany w rosyjskiej oświacie, które miały miejsce w latach 2013-2015, a zatem w trakcie prezydentury Władimira Putina. Skupiam się przy tym przede wszystkim na powstaniu Koncepcji nowego kompleksu edukacyjno-metodycznego w zakresie nauczania historii ojczystej oraz wprowadzeniu nowych podręczników do historii ojczystej (idea tzw. „jednego podręcznika"). W artykule staram się pokazać, że obraz WOW w nowych podręcznikach oparty jest głównie na sukcesie - Armii Czerwonej, Związku Socjalistycznych Republik Sowieckich i narodu sowieckiego.

Słowa kluczowe: Wielka Wojna Ojczyźniana; nauczanie historii; Rosja; polityka historyczna; Władimir Putin

\section{A WORD OF INTRODUCTION}

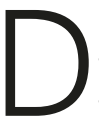
espite the fact that World War II ended more than seventy years ago, it remains the main pillar of collective memory of most societies and the historical policy of the countries which were involved in it (Machcewicz, 2010). Russia, however, appears to be a special case. The reasons can be sought, on the one hand, in the long-lasting effects of the war, such as the border changes in Europe or the enormous devastation and suffering it caused. But on the other hand, Russian collective memory preserves and passes on to successive generations the memory of war as a time of unity of the Soviet nation, heroism, sacrifice and will to fight for the liberation of Europe from Nazism. This results in the fact that the memory of war sometimes becomes more important for modern Russians than the events unfolding here and now. The situation is amplified by the fact that Russians as a society are proud of their wartime fate and achievements: of Stalin-a genius strategist and leader, or the two-and-a-half-year-long defense of Leningrad. This pride cannot be shaken even by events belonging to the sphere of "historical shame".

In Russia, public discussion about the past has become an important dimension of public debate which has been largely taken over by the authorities. The rulers effectively "suggest" narrations and interpretations of events and historical figures to the society, using different tools including naming streets, squares, building memorials and commemorative plaques, or exercising control over the education system. An incomparably bigger factor than any other event in the history of the Russian state affecting the national identity of modern Russians is the Great Patriotic War (GPW, 1941-1945). This trimmed-down and simplified variant of World War II has become one of the founding myths ${ }^{1}$ of the Russian society. And there is nothing strange about it. The victory of the Union of Soviet Socialist Republics (USSR) over Nazism is an ideal material to create a sacralized story about the Red Army's heroic fight against the Hitlerian enemy, sacrifice of the entire Soviet nation and saving Europe from Nazism. An excellent testimony to this is grand anniversary

\section{-....}

Talking about the GPW as a founding myth, it is impossible not to mention Poznań-based methodologist Jerzy Topolski. In his view, a myth is sacralized knowledge not subject to criticism, which reflects the reality in some way. The researcher considers mythical "any statements that are supposed to say something about the world which have spontaneously obtained or have been granted (by social, political forces or others) a status of factual or symbolic truths, not verified, "immobilized", sacralized to a lesser or greater degree" (Topolski, 1999, p. 204). I reject here the colloquial understanding of a myth as a made up (i.e., false) story. Instead, I treat it, in an anthropological way, as a story of symbolic importance. 
celebrations of the end of World War II on 9 May (Victory Day) whose importance and scope exceed all the other Russian holidays (Wołos, 2011).

The objective of this text is to show how the GPW is depicted in selected national history textbooks. Here, I consider textbooks not only as a source of knowledge about the past times, but also as a tool to create the state's historical policy and consequently a method to influence the identity of modern Russians and their perception of the past. Examining the fundamental myth of the Russian society in textbooks thus makes it possible to get a close look at how the rulers create the past in two ways. On the one hand, looking at their instrumental use of textbooks, and on the other, from the perspective of how the GPW is depicted in them.

An extremely interesting collective work in the field of comparative contemporary memory policy in the Central and Eastern European countries was published in 2014. Its editors, Michael Bernhard and Jan Kubik, did not take Russia into account when they constructed a comparative model aiming to explain differences in the understanding and use of specific past events found in particular countries. But the model is versatile enough to easily include both the Russian Federation (RF) and any other country in it. And so, the authors assumed that one event (or sometimes a set of closely connected events) is represented by one mnemonic regime i.e. a set of cultural and institutional practices designed to commemorate that event. A set of all the mnemonic regimes in turn makes a mnemonic field (Kubik \& Bernhard, 2014). If we take the concept of Kubik and Bernhard into consideration, the GPW will be one of the key mnemonic regimes for modern Russia. Moreover, the researchers also created typologies of mnemonic actors ${ }^{2}$, i.e. various entities that treat history instrumentally to create a vision to help them-to a greater or lesser degree-to gain or keep power. Russia is an excellent example of mnemonic warriors-mnemonic actors who draw a clear line between themselves (we) and other memory actors (they). Mnemonic warriors create and promote the only true-in their opinion-vision of the past they have developed ("guardians of the truth"), while others ("perpetuators of the falsehoods") push "wrong" or "false" versions of history (Kubik \& Bernhard, 2014, pp. 13-14). The fact that the Russian authorities consider themselves as the guardians of the past is evidenced e.g. by the law adopted in 2014 that introduced criminal liability for criticizing the actions of the USSR during World War $\|^{3}$ and rehabilitation of Nazism (Ugolovnyĭ kodeks, 2017). A teacher from Perm, Vladimir Luzgin, had to bear the consequences of deviating from the "only true" interpretation of history when a local court fined him 200,000 roubles in 2016 for posting a text on social media site VKontakte ${ }^{4}$ arguing that the Ribbentrop-Molotov pact allowed Hitler to start World War II and its signatories jointly invaded the Polish state on 1 September 1939, thus unleashing the war ${ }^{5}$.

2 Kubik and Bernhard identified the following mnemonic actors: mnemonic warriors, mnemonic pluralists, mnemonic abnegators, mnemonic prospectives (Kubik \& Bernhard, 2014).

3 The law mentions World War II rather than the Great Patriotic War. The RF authorities probably wanted the law to also cover the years 1939-1941, especially the Ribbentrop-Molotov Pact, still controversial in Russia, and the USSR attack on Poland on 17 September 1939.

420 people managed to read the text titled 15 facts about banderovci, or what the Kremlin is silent about (own transl.)

5 According to the court, Luzgin's remarks constituted "rehabilitation of Nazism" leading to a revision of the effects of World War II and were incompatible with the Nuremberg Tribunal ruling ("Rossiīskii sud zapretil rasskazyvat' o sotrudnichestve SSSR i natsistskoĭ Germanii", 2016). 
In 2013, President Vladimir Putin criticized the use of school textbooks presenting different points of view on the most important moments from the past of the Russian state and suggested that a uniform textbook for national history be created ("Zasedanie Soveta po mezhnatsional'nym otnosheniiam", 2013). This constituted an impulse for the creation of the Concept of a new educational and methodological complex for teaching national history (Kontseptsiia novogo uchebno-metodicheskogo kompleksa po otechestvennoi istorii, 2013) (hereinafter: the Concept) forming the basis of a new system of history teaching in Russian schools. The entities responsible for the creation of the document were the RF Ministry of Education and Science, the Russian Academy of Sciences [hereinafter: RAS], The Russian Historical Society [hereinafter: RHS] and the Russian Military History Society [hereinafter: RMHS]. These institutions formed the Working Group for the Development of the Textbook and Methodological Concept for National History [hereinafter: the Working Group] led by RF State Duma Chairman and RHS Chairman, Sergey Naryshkin7, RF Minister of Education and Science, Dmitri Livanov, and RMHS Chairman, Vladimir Medinsky. The director of the RAS Institute of World History, Alexandr Chubarian, became the scientific head of the project (Kontseptsiia novogo uchebno-metodicheskogo kompleksa po otechestvennoi istorii). Soon after the Concept (Kontseptsiia novogo uchebno-metodicheskogo kompleksa po otechestvennol istorii, 2013) was approved by RHS (October 2013), work began on the creation of the so-called "single textbook" (uniform textbook).

The new, uniform textbook was supposed to emphasize the joint struggle of the nation in the face of danger, develop a sense of pride in their country among students (including the achievements of GPW participants), promote patriotism and tolerance towards other nationalities. The new school textbook was also supposed to be a "guidepost" encourage students to independently draw conclusions ${ }^{9}$. However, during the work on the creation of the "single textbook" it was replaced with several publishing lines. As Livanov stressed in the "Izvestia" newspaper in August 2014: "There will probably be no unified history textbook. There will be only one historical and cultural standard in force, on the basis of which history textbooks will be developed. That doesn't mean there will be one textbook" ("V Rossii ne budet edinogo uchebnika istorii", 2014). In April 2015, RHS selected three textbook lines for school use: the lines by publishers Prosveŝenie (grades 6-10), Drofa (grades 6-10) and Russkoje slovo (grades 6-9). As Chubarian said, they would be handed to schools on 1 September 2015 ("Uchebniki po istorii trekh izdatel'stv uspeshno proshli èkspertizu RIO", 2015).

This way, the list of textbooks approved for use was reduced about 2.5-fold (the list from the schoolyear 2015/2016). Textbooks that had been used before were removed-

\section{-.....}

6 About the Concept of a new educational and methodological complex for teaching national history see more Hordecki (2014), Moskwa (2014, 2018), Portnov (2013).

7 Sergey Naryshkin was also the chairman of the 28-person Commission to Counteract Attempts at Falsifying History to Damage the Interests of Russia which operated in the RF in 2009-2012. The Commission's stated objective was to scientifically argue for the Russian interpretation of history, but de facto it was a propaganda tool in the hands of the authorities. The Commission was dissolved in 2012 (see: Ukaz Prezidenta Rossiīskoĭ Federatsii, 2009).

8 Orig. "navigator".

9 The new textbook should also contain information about the incorporation of two new entities-Crimea and the city of Sevastopol-into the RF. On 20 March 2014, at a joint meeting of RHS and the Council for Culture under the Chairman of the State Duma, a decision was taken for the Concept to include information about the incorporation of two new entities-Crimea and the city of Sevastopol-into the RF (Kontseptsiia novogo uchebno-metodicheskogo kompleksa po otechestvennoi istorii, 2013). 
because they were considered ineffective and unpatriotic. What is more, the lists of textbooks approved for use would now be created once in five years (rather than every year as before $)^{10}$. The implementation of the Concept was met with a negative response from most teachers and some publishers ("Utverzhden prikaz o Federal'nom perechne uchebnikov", 2014). The project was also criticized by members of the International Society Memorial, independent scientists and some media. It should also be stressed that the idea of a "single textbook" is a throwback to the Soviet times. Then, textbooks approved for school use had to be consistent with the Soviet interpretation of the past and greenlighted at the party and state levels ${ }^{11}$.

\section{THE PICTURE OF THE GREAT PATRIOTIC WAR IN SELECTED TEXTBOOKS}

Examining the way the Great Patriotic War is depicted in Russian national history textbooks appears reasonable since special attention is paid in the FR to what the Russians call "otiečestvennaâ istoriâ" ("native history" or "indigenous history"). A direct effect of this attachment to the history of the Russian state is that more hours are devoted to learning national history than world (general) history ${ }^{12}$. Russian historians also more often focus on internal problems at the time of the USSR than relations between the Soviet state and other countries. And it is reminded all the time in scientific and popular science discourse that the Soviet nation ${ }^{13}$ contributed to the USSR's success in the GPW, which in turn serves the legitimacy of the authorities, the state's power policy and integration of the Russian society around the idea of a jointly achieved victory over the enemy (Wołos, 2011).

Being aware of the number of textbooks for possible analysis, I have decided to focus only on those that have successfully passed the above mentioned RHS expert evaluation. This is a reasonable thing to do as they are used in Russian secondary schools and gradually displace other national history textbooks. Therefore, two school textbooks have been analyzed $^{14}$ : the textbook by publisher Drofa The History of Russia. Beginning of the $20^{\text {th }}$ Century-Beginning of the $21^{\text {st }}$ Century edited by Oleg Volobuev, Sergey Karpačev and Pëtr Romanov [hereinafter: the Volobuev textbook] (Volobuev, Karpachev, \& Romanov, 2016) and the textbook by publisher Prosveŝenie The history of Russia edited by Anatoly Torkunov [hereinafter: the Torkunov textbook] (Torkunov, 2016).

It is very clear to see in the chosen textbooks that memory about selected events and figures from the past of the Russian state is exaggerated and embellished. But moulding a collective memory that would be completely false is very difficult while it is much easier to inflate some fragments of history to the size of a myth important for the group (Sza-

\section{......}

10 A new list will be drawn up for the schoolyear 2017/2018 and for another five years it will not be possible to make any changes in it ("Knizhnyı skandal s Federal'nym perechnem uchebnikov", 2014).

11 More about historical education in the USSR see: Maresz (2017), Składanowski (2014).

12 In Russia, unlike Poland, two courses are run within one school subject (history): world history and history of Russia. In practice, however, teachers reduce the number of world history hours in favour of history of Russia.

13 Orig. sovetskij narod. In the Soviet period, the term narod usually meant either all the residents of the country-the popular sowietskij narod, or a description of ethnic (ethnocultural) communities-armian'skij narod, buriatskij narod. In modern science, Russian ethnologists and historians stress clearly that the term narod was understood in two different ways: both as a description of USSR residents not bound by ethnic ties and a description of ethnic communities, see more: Semenov (n.d.), Tishkov $(2010,2011)$.

14 The textbook by publisher Russkoe slovo was not taken into consideration as it covers the period up to 1914. 
cka, 2006). An example of this is the GPW (the founding myth) which consists of many smaller triumphs (e.g., the Battle of Stalingrad) and myths (e.g., the myth of a soldier-liberator). Each of them is depicted, on the one hand, as a separate event, and on the other as a component of the USSR's victory over the Nazi enemy. For the GPW is inalterably "immobilized" and "sacralized" as the basis of school historiography. Talking about 1941-1945, therefore, we encounter heroic history, highlighting the military successes of the Soviet state, glossing over its setbacks and defeats.

The axis around which the picture of the GPW'15 is constructed is success ${ }^{16}$. And there is nothing strange here as the Russian authorities are aware that belief in past victories consolidates the nation in a sense of pride and satisfaction in its superiority over the real or imagined "enemy". Therefore, when there is no basis to talk about triumph, the rulers can turn any defeat into a victory of the Soviet nation, the Red Army or the military industry. Thus, in the context of the GPW, the term defeat is virtually non-existent.

In the analyzed textbooks, the victory over Hitler's Germany is stressed at almost every step-in the description of the defense of the capital city, the Stalingrad battle, the Battle of Kursk or the Siege of Leningrad. Take the defense of Stalingrad-both textbooks emphasize that it was a success of the Red Army and a decisive event not only in the GPW, but in the entire World War II. In the Volobuev textbook, minor events-successes form a component of the picture of the city's defense: the 58-day defense of Pavlov's house and the clashes over Mamaev Kurgan (one of the battle's major strategic spots). In both textbooks, the most important part of the battle is Operation Uranus, a counteroffensive of the Soviet forces on 19-20 November 1942 which led to the encirclement of general Friedrich Paulus's 6th Army and its surrender ${ }^{17}$. In the Volobuev textbook, we can also read that the Red Army's success at Stalingrad strengthened the Soviet nation's faith in victory (Volobuev et al., 2016). The Battle of Kursk has been depicted similarly to the defense of Stalingrad. Both textbooks strongly emphasize that despite a powerful attack by the German forces, the Red Army withstood the assault ${ }^{18}$ and the Germans failed to achieve the expected results (Volobuev et al., 2016). The textbooks single out the Battle of Prokhorovka (12 July 1943) as part of the picture of the Battle of Kursk, stressing that it was the biggest tank battle of World War II and describing it as a victory of the USSR, even if the word "victory" or "success" does not appear even once. Instead, they say that "the Germans were forced onto the defensive" (Torkunov, 2016, p. 48) or "the Germans were forced to retreat to their starting positions" (Volobuev et al., 2016, p. 168). We also read in the Volobuev textbook that the Battle of Kursk decisively undermined the German tank and air power and along with the Soviet attack in Left-Bank Ukraine ${ }^{19}$ led to the loss of strategic initiative by the Wehrmacht (Volobuev et al., 2016).

15 I would like to stress at this point that the objective of this article is not to describe how the GPW proceeded, but rather how it was depicted in selected textbooks. Therefore, I am not interested in the history itself, but its interpretation.

16 Success is understood as a "successful outcome of an undertaking, achieving the objective pursued" (Dubisz, 2008, p. 147).

17 General Friedrich Paulus is the only German army general mentioned by name and surname in the textbooks (Torkunov, 2016; Volobuev et al., 2016).

18 There are differences, however, on the issue of how deep inside the Soviet state's territory the German forces advanced. We read in the Volobuev textbook that during the attack against the Red Army the Germans moved maximum 10-12 km into the USSR territory, while Torkunov talks about 30-35 kilometres. The differences can result from the fact that the German forces managed to advance $10-12 \mathrm{~km}$ in the north, $35 \mathrm{~km}$ in the south into the Soviet Union territory (Torkunov, 2016; Volobuev et al., 2016).

19 Meaning the liberation of Kiev (6 November 1943) and Crimea with Sevastopol (late May 1944) (Volobuev et al., 2016). 
All the minor triumphs of the Soviet state lead to the Year of victory: the surrender of Germany and Japan (Volobuev et al., 2016, p. 194)20. Both textbooks describe in detail the Berlin operation (April 1945) carried out in the Eastern Front by the forces of the 1st and 2nd Belorussian Front and the 1st Ukrainian Front (Volobuev et al., 2016). Volobuev emphasizes here that the strength of the Red Army lay not in the number of soldiers or their battle experience, but in the patriotic spirit among the fighters. In both textbooks, we also find a description of the battle for the Reichstag and the symbolic placement of a red flag over the Reich's parliament by two Soviet soldiers on 30 April (a Torkunov textbook emphasizes that the flag was a symbol of victory). There is also information about the final surrender of the German side on 2 May 1945, the signing of the act of capitulation of the Third Reich on the night of 8/9 May 1945 and the designation of 9 May as Victory Day (Volobuev et al., 2016). Torkunov also points out that a Victory Parade took place on the Red Square on 24 June after a break of 4 years (Torkunov, 2016). But the victory of the USSR in the GPW is not only the defeat of Hitler's Germany, but also Japan. We learn from both school textbooks that the act of Japan's surrender was signed on 2 September 1945 aboard the battleship "Missouri" in the Bay of Tokyo.

In the Torkunov textbook, the victory of the USSR in World War II (rather than the GPW) means a collapse of dictatorial regimes. It is emphasized that the defeat of Nazi Germany and Japan boosted the authority of the Soviet state, which now became a superpower. What is more, the triumph of the multiethnic Soviet nation in the bloodiest and cruelest war in the history of mankind became the most important event for the Russian state: "the heroic deed of the victors will never be forgotten", and one of the GPW's effects was "saving the lives and future of the Soviet nations" (Torkunov, 2016, p. 67). Furthermore, both textbooks stress explicitly that the USSR's triumph in the war was partly possible thanks to the spiritual and patriotic support of the Soviet nation which kept believing in a final victory throughout the GPW.

As success is the main pillar of the picture of the Great Patriotic War, the term defeat is practically nowhere to be seen ${ }^{21}$. It only appears when the activities of Germany-the main enemy of the USSR in the GPW-are described (the USSR's success-Germany's defeat). Even though Torkunov talks more directly about Soviet military setbacks-one of the paragraphs is even entitled "Red Army defeats summer-autumn 1941" (Torkunov, 2016, p. 14), all those setbacks are depicted as events that-despite the heroism of Soviet soldiers and patriotism of the Soviet nation-could not have been avoided, partly due to Germany's advantage in terms of numbers, technical equipment, experience, qualified commanders etc. (Torkunov, 2016). In both textbooks, we can also find examples of turning defeat into triumph. An excellent example here is the "heroic defence of Sevastopol" in 1942. It is a particularly interesting case as the Battle of Sevastopol ended in a defeat of the Red Army-Torkunov even calls it a "tragedy of the Soviet forces" that led to the capture of the entire Crimea by the enemy (Torkunov, 2016, p. 26), Volobuev-a "disaster and high number of casualties" (Volobuev et al., 2016, pp. 162-163). Despite the debacle of the Soviet forces, there is no mention of defeat, but of a heroic 250-day defense of the city and the Kerch Peninsula (withstanding the enemy's assault until July 1942) (Torkunov, 2016; Volobuev et al., 2016).

20 The title of one of the subchapters in the Volobuev textbook.

21 Defeat of the Soviet forces is explicitly mentioned in the description of the German occupation of Lithuania, Latvia and Estonia, in the Volobuev textbook also with regard to the Red Army's defeat at Kiev (September 1941). 
When talking about how the picture of the GPW is created in selected textbooks, it is impossible to overlook one of the most deeply embedded events of that period in the Russian consciousness, i.e. the siege of Leningrad (8 October 1941-27 January 1944). That's because the description of the city's siege contains all the elements characteristic for the Russian narration about the war. First, the role of the Soviet nation and cooperation between the front and the hinterland are highlighted. Second, the success of the Soviet state (preventing the capture of the city) is emphasized, and third, the picture of the siege is filled with values such as: patriotism, heroism and the fighting spirit of soldiers and city residents. In the Volobuev textbook, already the title of the subchapter dedicated to the city's siege points to the role the Soviet nation played in its defense: Besieged Leningrad. "We Resisted. We Fought. We Won" (Volobuev et al., 2016, pp. 168-169). The title is a fragment of the poem by Vera Inbier Salvoes of Victory which is embedded into the contents of the textbook: "Glory to You, great city, which joined together the battlefront fighters and the society, and which under incredible difficulties resisted, fought, won" (Volobuev et al., 2016, pp. 168-169). In the Volobuev book, the plight of Leningrad residents and the joint fight of the front and the hinterland are also underlined with a poem by Yuri Voronov 31 December 1941: "Misery in the besieged city has no limits: we go deaf from the roar of bullets, only eyes and cheekbones are left from our pre-war faces" (Volobuev et al., 2016, pp. 168-169). The textbook also emphasizes the role that radio played in maintaining the fighting spirit of the city's residents, especially the prose and poetry of Olga Bergholz that was broadcast: "I say: we, Leningrad residents, can't be shaken by the roar of cannons, and if there are barricades tomorrow, we won't leave our barricades"22 (Volobuev et al., 2016, pp. 168-169). We also read in the Torkunov textbook that withstanding the siege of the city reinforced the Soviet nation's faith in victory over Nazi Germany (Torkunov, 2016), and in the Volobuev textbook that Leningrad became a symbol of "the population's perseverance in the Great Patriotic War" (Volobuev et al., 2016, p. 170). Difficult conditions in the besieged city are also illustrated graphically. In the Volobuev textbook, with the use of two photos: of the bread ration in the besieged city and of a food coupon (Volobuev et al., 2016); in the Torkunov textbook, with a photo titled In the besieged Leningrad. 1942, which shows warmly dressed people drawing water in their buckets and jugs in the snow-covered city (Torkunov, 2016).

In the picture of the siege of Leningrad, Germany's defeat isn't shown, the emphasis is more on the victory of the Soviet nation which managed to withstand the siege of the city despite all the difficulties (Torkunov, 2016; Volobuev et al., 2016). The only thing that can be surprising in this picture is the fact that marshal Georgy Žhukov², who is credited with organizing the successful defense of Leningrad, is completely overlooked. Neither Volobuev nor Torkunov mention Žhukov even once. Similarly to defeat, in the textbooks the number of victims is not mentioned too often. Only Torkunov includes information about the victims in the picture of the Siege of Leningrad: more than 1 million city residents are thought to have died from hunger, diseases, bombardments (Torkunov, 2016).

22 The quoted fragment is a verse of Olga Bergholz's poem Poetry of the heroic deed.

23 Marshal Georgy Žhukov (1896-1974), one of Stalin's close associates, a hero of the Great Patriotic War, commanded the defense of Leningrad and Moscow. Appointed Deputy Chief of General Staff in August 1942, he was a member of Stavka where he played a key role in preparing the Soviet forces for the Battles of Stalingrad, Kursk, in Ukraine or Belarus. He personally commanded the final attack of the 1st Belorussian Front on Berlin. In May 1945, Žhukov accepted Germany's surrender, see: Mawdsley (2011), Spahr (2002). 
A characteristic thing for both textbooks is that heroes are created out of ordinary people. The figure of 11-year-old Tanya Savicheva appears in the description of the siege of Leningrad both in the Volobuev and Torkunov textbooks. During the siege-it is saidshe kept a diary where she recorded information about deaths of her family members. Volobuev quotes the last entry in the diary: "Everyone has died, Tanâ is left all alone" (Volobuev et al., 2016, p. 170), Torkunov-its entirety: "Leka died on 17 March at 5 in the morning 1942. Grandpa Vasâ died on 13 April at 2 at night 1942. Grandpa Loša on 10 May at 4 in the day 1942. Mum on 13 May at 7.30 in the morning 1942. Savičove have died. Everyone has died. Tanâ is left all alone" (Torkunov, 2016, p. 21). The Torkunov book also emphasizes that Tanya's diary became a "symbol of the terrible period of the siege" (Torkunov, 2016, p. 21).

\section{CONCLUSION}

1939 is almost non-existent in the historical consciousness of Russians. The years 19391941 are a territorially limited conflict for them. The date of Nazi Germany's aggression against the USSR and the beginning of the GPW-22 June 1941—remains a defining moment for the Russian historiography (Wołos, 2011). This is also seen in Russian national history textbooks. The picture of the GPW created in them consists of a streak of military victories, a joint fight of all the USSR nations against the enemy, heroism and sacrifice. Defeat is hardly ever mentioned, at least in the context of the Soviet state's setbacks. The elements used in the description of the GPW are very clearly seen in the picture of the siege of Leningrad. We find there both the sacrifice of the Soviet nation for the motherland and the belief in victory over the enemy.

In Russia, officials and politicians who develop the school curriculum are the decisionmakers on the issue of textbook contents. Selection of historical material is indeed made at the ministry level. On the one hand, the implementation of the Concept, on the other, the shaping of the obligatory vision of the GPW in schools constitute an excellent example of how the historical policy of the Russian state is formed. And it is completely natural here that textbooks build historical consciousness mainly on "unequivocally" positive events and figures or those whose "morally equivocal" choices are effectively ignored. Even if the mnemonic field of the Russian Federation is much broader (its scope also includes the 1917 Revolutions, the Empire of Peter the Great, or the year of 1612, to name a few), the Victory Day celebrated on 9 May is considered by the Russians as one of their major holidays - right after the New Year, their own birthdays and those of their closest ones (Levada-TSentr, 2014). Moreover, as many as 85 percent of Russians have war veterans in their families, while 68 percent are relatives of someone who died during the war (Levada-TSentr, 2016). The impact of the GPW myth is thus enormous. This partly explains why there is a gradual return to the cult of Stalin, "historical lies" are penalized, and textbooks presenting a uniform interpretation of history are introduced in schools. When looking into the uniformization of history teaching in schools and the functioning of the GPW myth in the Russian society, it can be therefore concluded that such measures are a part of the bigger picture-a complex of deliberate efforts by the Russian authorities to mould Russians into citizens who, believing in shared ideals, will be ready to stand up in defense of the motherland at any time. Just like their ancestors did at the time of the Great Patriotic War. 
Czubiński, A. (2004). Historia drugiej wojny światowej 1939-1945. Poznań: Dom Wydawniczy Rebis.

Dubisz, S. (2008). Sukces. W S. Dubisz, Uniwersalny słownik języka polskiego PWN. Warszawa: PWN.

Hordecki, B. (2014). Wokół dyskusji nad ujednoliceniem szkolnej recepcji historii w Federacji Rosyjskiej. Sensus Historiae, 16(3), 103-134.

"Knizhnyi" skandal s Federal'nym perechnem uchebnikov nabiraet oboroty. (2014, March 21). Retrieved May 20, 2018, from http://www.mk.ru/social/education/ article/2014/03/21/1002098-knizhnyiy-skandal-s-federalnyim-perechnem-uchebnikovnabiraet-oborotyi.html

Kontseptsiia novogo uchebno-metodicheskogo kompleksa po otechestvennoĭ istorii. (2013). Retrieved May 20, 2018, from http://www.iriran.ru/?q=node/1039

Kubik, J., \& Bernhard, M. (2014). A theory of the politics of memory. W M. Bernhard \& J. Kubik (Ed.), Twenty years after communism: The politics of memory and commemoration (pp. 7-34). Oxford: Oxford University Press.

Levada-TSentr. (2014, February 20). Vazhnye prazdniki. Retrieved May 20, 2018, from http://www.levada.ru/2014/02/20/vazhnye-prazdniki/

Levada-TSentr. (2016, June 21). Vtoraia mirovaia voīna. Retrieved May 20, 2018, from http://www.levada.ru/2016/06/21/vtoraya-mirovaya-vojna/

Machcewicz, P. (2010). Wstęp. W P. Kwiatkowski, L. Nijakowski, B. Szacka, \& A. Szpociński (Eds.), Między codziennością a wielką historią: Druga wojna światowa w pamięci zbiorowej społeczeństwa polskiego (pp. 7-11). Gdańsk: Wydawnictwo Naukowe SCHOLAR.

Maresz, T. (2017). Polska i Polacy w radzieckiej szkolnej narracji podręcznikowej. Bydgoszcz: Wydawnictwo Uniwersytetu Kazimierza Wielkiego.

Mawdsley, E. (2011). I/ wojna światowa: Nowe ujęcie (B. Gutowska-Nowak, Trans.). Kraków: Wydawnictwo Uniwersytetu Jagiellońskiego.

Moskwa, D. (2014). "Putinowska" wizja przeszłości: Nowa koncepcja nauczania historii w świetle polityki historycznej Federacji Rosyjskiej. Historia i Polityka: Pótrocznik poświęcony myśli politycznej i stosunkom międzynarodowym, 2014(11(18)), 93-106. https://doi.org/10.12775/HiP.2014.008

Moskwa, D. (2018). Russia: An incessant battle for education. Historia i Polityka: Pótrocznik poświęcony myśli politycznej i stosunkom międzynarodowym, 2018(24(31)), 3346. https://doi.org/10.12775/HiP.2018.009

Portnov, A. (2013). Uchebnik istorii po goszakazu. Ab Imperio, 2013(3), 388-396.

Rossiīskiĭ sud zapretil rasskazyvat' o sotrudnichestve SSSR i natsistskoi Germanii. (2016, July 1). Retrieved May 20, 2018, from http://www.mk.ru/social/2016/07/01/rossiyskiysud-zapretil-rasskazyvat-o-sotrudnichestve-sssr-i-nacistskoy-germanii.html

Semenov, I. (n.d.). Rasy, natsii, ètnosy. Skepsis. Retrieved May 20, 2018, from http:// scepsis.net/library/id_75.html

Składanowski, H. (2014). Relacje sowiecko-polskie w podrecznikach do nauczania historii w systemie oświatowym Rosji Bolszewickiej i ZSRS w latach 1917-1991. Toruń: Dom Wydawniczy DUET.

Spahr, W. J. (2002). Żukow (M. Pindel, Trans.). Warszawa: Dom Wydawniczy Bellona.

Szacka, B. (2006). Pamięć i mit. Warszawa: Wydawnictwo ISP PAN. 
Tishkov, V. (2010). Rossiïskii narod: Kniga dlia uchitelia. Moskva: Prosveshchenie.

Tishkov, V. (2011). Etnopolitologiia: Politicheskie funktsii étnichnosti. Moskva: Izdatel'stvo MGU.

Topolski, J. (1999). Jak sie pisze i rozumie historie: Tajemnice narracji historycznej. Warszawa: Oficyna Wydawnicza RYTM.

Torkunov, A. V. (Ed.). (2016). Istoriia Rossii: Uchebnik dlia obshcheobrazovatel'nykh organizatsii v trëkh chastiakh (10 klass). Moskva: Prosveshchenie.

Uchebniki po istorii trekh izdatel'stv uspeshno proshli èkspertizu RIO. (2015, April 24). Retrieved May 20, 2018, from http://ria.ru/society/20150424/1060644304.html

Ugolovnyı̆ kodeks (st. 354.1 UK RF v red. 2017). (2017). Retrieved May 20, 2018, from http://www.consultant.ru/document/cons_doc_LAW_10699/be763c1b6a1402144cabfe17a0e2d602d4bb7598/

Ukaz Prezidenta Rossiīskoĭ Federatsii ot 15 maia 2009 goda N 549, O Komissii pri Prezidente Rossiīskoi Federatsii po protivodeǐstviiu popytkam fal'sifikatsii istorii w ushcherb interesam Rossii. (2009). Retrieved from http://document.kremlin.ru/doc. asp? $\mid \mathrm{D}=52421 \& \mathrm{PSC}=1 \& \mathrm{PT}=1 \& \mathrm{Page}=2$

Utverzhden prikaz o Federal'nom perechne uchebnikov na 2014-2015 uchebnyı̆ god. (2014, May 5). Retrieved May 20, 2018, from http://pro-books.ru/news/3/14873

Wołos, M. (2011). Historiografia rosyjska pierwszej dekady XXI stulecia wobec historii Związku Radzieckiego oraz węzłowych problemów z dziejów stosunków polsko-radzieckich (zarys problematyki). Dzieje Najnowsze, 2011(3), 133-154.

$\checkmark$ Rossii ne budet edinogo uchebnika istorii. (2014, August 27). Retrieved May 20, 2018, from http://www.bbc.co.uk/russian/russia/2014/08/140827_russia_history_textbook

Volobuev, O. V., Karpachev, S. P., \& Romanov, P. N. (Eds.). (2016). Istoriia Rossii: Nachalo XX - nachalo XXI veka (10 klass). Moskva: Drofa.

Zasedanie Soveta po mezhnatsional'nym otnosheniiam-stenograficheskii otchët. (2013, February 19). Retrieved May 20, 2018, from http://state.kremlin.ru/council/28/ news/17536 